\title{
PLURICENTRYZM W NIEMIECKIM JEZZYKU STANDARDOWYM I SPECJALISTYCZNYM
}

\author{
Artur Dariusz KUBACKI, dr hab. \\ Instytut Filologii Germańskiej, Uniwersytet Śląski w Katowicach \\ ul. gen. S. Grota-Roweckiego 5, 41-200 Sosnowiec \\ kubart@post.pl
}

\begin{abstract}
Abstrakt: W niniejszym artykule poddano analizie zjawisko pluricentryzmu/policentryzmu w niemieckim języku standardowym i specjalistycznym. Do końca lat 80 . XX wieku język niemiecki traktowano jeszcze jako język monocentryczny, a odmianę używaną na obszarze Niemiec uważano za wzorcową i jedynie normotwórczą. Miało to bezpośredni wpływ na sposób nauczania języka niemieckiego jako języka obcego, m.in. w Polsce, gdyż w procesie dydaktycznym odnoszono się jedynie do realiów społeczno-politycznych i gospodarczych Niemiec. Nawet na studiach germanistycznych rzadko omawiano odmiany języka niemieckiego używane w pozostałych krajach niemieckojęzycznych, jak Austria, Szwajcaria, Luksemburg i Liechtenstein. W ogóle natomiast nie mówiono na nich o niemczyźnie używanej w Belgii Wschodniej i Tyrolu Południowym we Włoszech. Różnice w odmianach języka niemieckiego uwidaczniają się na każdej płaszczyźnie języka: fonetycznej, morfologicznej, składniowej, leksykalnej, a nawet pragmatycznej. Co ciekawe, dotyczą one nie tylko języka standardowego (Gesamtsprache), lecz także języka specjalistycznego (Fachsprache). Przedmiotem niniejszego artykułu jest wskazanie na te różnice w odniesieniu zarówno do języka standardowego, jak i specjalistycznego, a także na wynikające z nich implikacje dydaktyczne dla glottodydaktyki i translatoryki.
\end{abstract}

Słowa kluczowe: komparatystyka legilingwistyczna, pluricentryzm, policentryzm, język specjalistyczny, język standardowy

\section{PLURICENTRISM IN THE GERMAN STANDARD LANGUAGE AND THE GERMAN LANGUAGE FOR SPECIAL PURPOSES}

\begin{abstract}
In this article, the author analyses pluricentrism/polycentrism in the German standard language and the German LSP. Until the eighties of the 20th century, the German language was treated as a monocentric language and the variant used in Germany was perceived as the model and normative variant. This had a direct impact on the method of teaching German as a foreign language (also in Poland). In the process of teaching, teachers referred only to social, political and economic situation in Germany. Even during German language university courses the variants of the German language used in other German-speaking countries, such as Austria, Switzerland, Luxembourg and Liechtenstein, were rarely discussed and the German language used in Eastern Belgium and Southern Tyrol in Italy was never mentioned. The differences between the variants of the German language can be seen at every level of the language: phonetic, morphological, syntactic, lexical and even pragmatic one. What is interesting, they can be found not only in the standard language (Gesamtsprache), but also in LSP (Fachsprache). In the article, the author shows these differences with regard to both the standard language and LSP. Moreover, he analyses their consequences for German language teaching and the process of translation.
\end{abstract}

Key words: comparative legilinguistics, pluricentrism, polycentrism, LSP, standard language 


\section{Wstęp}

Niniejszy artykuł ma na celu przybliżenie zjawiska pluricentryzmu (Plurizentrismus/ Plurizentrizität) ${ }^{1}$ języka niemieckiego, czyli - jak wyjaśnia Aleksander Szulc $(2005,25)$ - używania języka niemieckiego „w całkowicie niezależnych od siebie państwach, których obywatele nie zawsze identyfikują się pod względem narodowościowym z Niemcami”. Jeszcze do końca lat 80 . XX wieku język niemiecki uważano za język monocentryczny, tzn. taki, który posiada jeden standard w Niemczech obowiązujący jako wariant główny, względnie norma. Język niemiecki używany w Austrii, Szwajcarii i Tyrolu Południowym traktowano jako wariant poboczny lub „odchylenie” od normy.

Jak zauważa Elisabeth Lang $(2010,197)$, pluricentryzm ${ }^{2}$ języka niemieckiego stał się dopiero w latach 90. obiektem zintensyfikowanych badań językoznawczych ${ }^{3}$. Rozważania naukowe na ten temat podejmowali m.in. Ulrich Ammon $(1995,1996,1998)$ z Niemiec, Wolfgang Pollak (1994), Rudolf Muhr (1997, 2012) oraz Rudolf de Cillia (2006) z Austrii, a także germanista Michael G. Clyne $(1995,2005)$ z Australii. W Polsce już od 1999 r. prowadzone są pogłębione badania na temat odmian narodowych języka niemieckiego jako zjawiska językowego w ogóle (Szulc 1999). Powstały też na ten temat drobne przyczynki autorstwa np. Anny Dargiewicz (2004), Artura D. Kubackiego (2011a), Sylwii Firyn (2010, 2012) czy Karoliny Paluszek (2014). Natomiast w odniesieniu do pluricentryzmu obecnego także w językach fachowych czy translatoryce $\mathrm{w}$ szczególności takich badań systematycznych wciąż brakuje. Pewien wyjątek stanowi tu wkład związanego naukowo $\mathrm{z}$ Uniwersytetem Warszawskim austriackiego badacza Rheinholda Utriego (2010, 2012, 2013a, 2013b), który w swoich licznych artykułach zajmuje się pluricentryzmem niemczyzny standardowej i specjalistycznej, prezentując liczne przykłady różnic w zakresie jej użycia w Austrii. W przypadku pozostałych odmian języka niemieckiego nadal istnieje luka, jeżeli chodzi o tego typu opracowania.

\footnotetext{
${ }^{1}$ Pluricentryzm/policentryzm (także język pluricentryczny/policentryczny) jako przeciwieństwo monocentryzmu to terminy, których wprawdzie formalnie nie odnotowano jeszcze w polskich słownikach językoznawczych, ale coraz częściej stosowane są w nauce na określenie odmian narodowych danego języka. Terminy mono- i policentryzm do literatury przedmiotu wprowadził Michael Clyne (zob. Szulc 1999, 236-237).

${ }^{2}$ Ammon (1998, 313 i n.) interpretuje zjawisko pluricentryzmu języka niemieckiego w trojaki sposób. Wyróżnia model pluricentryczny (plurizentrisches Modell), model plurinarodowy (plurinationales Modell) oraz model pluriareałowy (pluriareales Modell). W pierwszym modelu stawia znak równości między różnymi narodami a różnymi centrami języka niemieckiego. W drugim modelu zakłada istnienie - w odniesieniu do języka pisanego i standardowego wspólnej części zasobów języka niemieckiego dla Niemców, Austriaków i niemieckojęzycznych Helwetów. Natomiast trzeci model - jego zdaniem - dotyczy jedynie odmiany języka niemieckiego używanej w Austrii, która rozumiana jest jako wariant południowoniemiecki (stąd w nazwie modelu areał jako synonim obszaru, powierzchni).

${ }^{3}$ Dział językoznawstwa zajmujący się takimi badaniami to lingwistyka odmian narodowych danego języka (Varietätenlinguistik).
} 


\section{Comparative Legilinguistics 17/2014}

Konceptualizacja języka niemieckiego jako języka pluri-/policentrycznego (pluri-/polyzentrische Sprache) obejmuje trzy równoważne odmiany ${ }^{4}$ języka, zwane inaczej standardami lub wariantami języka (por. de Cillia 2006, 51; Clyne 1995, 20): (1) odmianę niemiecką (deutschländisches Deutsch, Bundesdeutsch, Binnendeutsch), (2) odmianę austriacką (österreichisches Standarddeutsch) oraz (3) odmianę szwajcarską (Schweizerhochdeutsch). Natomiast różnice językowe - zresztą nie tylko w odniesieniu do warstwy leksykalnej - odróżniające użycie niemczyzny w tych trzech krajach niemieckojęzycznych określa się odpowiednio terminami: teutonizmy (Teutonismen, Deutschlandismen, Bundesgermanismen), austriacyzmy (Austriazismen) i helwetyzmy (Helvetismen) (por. Pollak 1994, 12; Meyer 2006, 16; Firyn 2012, 51-52).

Poza językiem niemieckim do indoeuropejskich języków pluricentrycznych zalicza się także języki: angielski, francuski, hiszpański i portugalski (por. Clyne 1995, 20), a ostatnio także nawet włoski (zob. Muhr 2012).

Zgodnie z opisem języków pluricentrycznych Ulricha Ammona (1995, 96-97) za język pluricentryczny należy uznać każdy język, który posiada kilka wariantów standardowych obowiązujących w różnych państwach, choć niekoniecznie musi on mieć status języka urzędowego ${ }^{5}$. Ponadto państwa mające „własny” standardowy wariant języka dysponują narzędziami normatywnymi w postaci słowników, zasad pisowni, wymowy czy gramatyki, czyli - inaczej mówiąc - posiadają tzw. „kodeks lingwistyczny” (linguistischer Kodex). W przypadku Austrii źródłem normatywnym jest np. Österreichisches Wörterbuch (2006), dla Niemiec jest to np. seria słowników Dudena, w tym obszerny Universalwörterbuch Duden (2011), a dla niemieckojęzycznej Szwajcarii są to takie pozycje słownikowe, jak np. Unser Wortschatz, Schweizer Wörterbuch der deutschen Sprache autorstwa Ingrid Bigler (1987) lub Schweizer Wörterbuch. So sagen wir in der Schweiz autorstwa Kurta Meyera (2006) ${ }^{6}$.

Ulrich Ammon $(1995,96)$ wyróżnia trzy pełne ośrodki (centra) językowe (Vollzentren) oraz cztery półośrodki (półcentra) językowe (Halbzentren). Pełne ośrodki językowe to Niemcy, Austria i niemieckojęzyczna Szwajcaria, które posiadają kodeksy lingwistyczne dla używanego w nich standardu. Półośrodki językowe to Liechtenstein, Luksemburg, Belgia Wschodnia oraz Tyrol Południowy, które nie posiadają takiego kodeksu. Heidemarie Markhardt $(2006,9)$ twierdzi nawet, iż norma języka ogólnego (Gesamtsprache) z reguły kształtowana jest przez pełne ośrodki językowe.

\section{Specyfika standardu języka niemieckiego w Austrii}

Dla przedstawienia sytuacji językowej w Austrii należy zwrócić uwagę na jej położenie geograficzne i uwarunkowania historyczne. Jak słusznie zauważa Szulc $(1999,155)$, nie

\footnotetext{
${ }^{4}$ Definicje wariantu i odmiany języka można znaleźć u Szulca (1999, 21-22).

${ }^{5}$ Przypomnijmy, iż język niemiecki posiada status języka urzędowego w takich krajach Europy, jak: Republika Federalna Niemiec, Republika Austrii, Konfederacja Szwajcarska, Księstwo Liechtensteinu, Wielkie Księstwo Luksemburga, Królestwo Belgii (Belgia Wschodnia), Republika Włoska (Tyrol Południowy). W ostatnich trzech państwach pełni on funkcję języka regionu.

${ }^{6}$ Jak słusznie zauważa Ulrich Ammon $(1995,96)$, kodeksy lingwistyczne muszą być opracowane przez specjalistów danego kraju niemieckojęzycznego, ale nie muszą być w nim drukowane (np. słownik Kurta Meyera poświęcony niemczyźnie szwajcarskiej został wydrukowany w Wiedniu).
} 
Artur Dariusz Kubacki, Policentryzm w niemieckim języku standardowym...

bez znaczenia jest fakt, iż Austria leży niemal w całości na bawarskim obszarze etnicznym i dialektalnym. Spowodowało to, iż niemczyzna austriacka wyrosła na gruncie dialektów górnoniemieckich (Oberdeutsch), którymi posługiwano się w południowych Niemczech, zwłaszcza w Bawarii. Językiem Austriaków stał się język niemiecki w swej odmianie narodowej (por. Szulc 1999, 162).

Po Drugiej Wojnie Światowej Republika Austrii dążyła wyraźnie do odgraniczenia swojego języka i podkreślenia własnej odrębności od faszystowskich.

Niemiec, co znalazło wyraz m.in. w stosowaniu na świadectwach szkolnych dla przedmiotu język niemiecki terminu Unterrichtssprache (dosł. język nauczania/język wykładowy), a nie Deutsch (por. Szulc 1999, 161; Bęza 2004, 189). Ponadto już w 1951 r. Austriacy opracowali swój pierwszy słownik pt. Österreichisches Wörterbuch (ÖWB), w którym umieszczono ponad 20.000 haseł kodyfikujących słownictwo używane na terytorium Republiki Austriackiej (por. Kubacki 2011a, 212). Poniżej zamieszczam obszerny cytat z Przedmowy do tego słownika doskonale charakteryzujący pod względem lingwistycznym niemczyznę austriacką oraz uzasadniający jej użycie przez obywateli Austrii (ÖWB 1951, 6-7):

Das Österreichische Wörterbuch ist ein Wörterbuch der guten, richtigen deutschen Gemeinsprache. Es ist jedoch in erster Linie für Österreicher bestimmt und wird vor allem von Österreichern benützt werden. Deshalb enthält es auch zahlreiche allgemein verwendete Wörter der österreichischen Umgangssprache und der österreichischen Mundarten, wenngleich keine Wörter in mundartlicher Schreibung. Solche Wörter sind aber ausdrücklich als der Umgangssprache oder der Mundart zugehörig gekennzeichnet, und neben ihnen stehen gemeinsprachliche Ausdrücke. (...).

Das Österreichische Wörterbuch ist noch in einem anderen Sinn als ein österreichisches anzusprechen. Wir Österreicher verwenden eine Reihe von Ausdrücken, die nicht weniger richtig, gut und schön sind als anderswo gebrauchte. Sie wurden naturgemäß im Wörterbuch bevorzugt, wogegen etwa nur in Norddeutschland übliche gar nicht berücksichtigt oder als bei uns fremd oder zumindest ungewohnt ausdrücklich gekennzeichnet wurden. Es ist aber auch Tatsache, daß wir in der besten Sprache der Gebildeten unseres Landes Wörter anders betonen, anders aussprechen, Hauptwörter mit einem anderen Artikel oder einer anderen Mehrzahlform, Zeitwörter mit einem anderen Hilfszeitwort verwenden u. v. a. m., als dies außerhalb Österreichs üblich ist. In solchen Fällen wurde die bei uns gebräuchlichen, allgemein als gut und richtig empfundenen Formen ins Wörterbuch aufgenommen.

Austriacka odmiana języka niemieckiego stwarza problemy nie tylko ze względu na akcent i intonację. Przede wszystkim różnice widoczne są w otwartym systemie leksykalnym niemczyzny austriackiej, a także - w mniejszym stopniu - w jej podsystemach: morfologicznym, słowotwórczym i składniowym (zob. Szulc 1999, 165), o czym mogliśmy się już częściowo dowiedzieć z przytoczonej powyżej Przedmowy do słownika austriackiego. Ponadto w Austrii występuje olbrzymia ilość dialektów i gwar, które powstały w wyniku izolacji terenów wysokogórskich, np. dialekt Vorarlbergu jest bliższy szwajcarskiej odmianie języka niemieckiego, tzw. Schwyzerdütsch. Jest to uwarunkowane tym, iż dialekt używany w Voralbergu należy do grupy dialektów alemańskich charakterystycznych dla Szwajcarii i Liechtensteinu, a nie bawarskoaustriackich, które są typowe dla pozostałej części Austrii. 


\section{Comparative Legilinguistics 17/2014}

Z badań Petera Wiesingera (za Szulcem 1999, 166) wynika jednoznacznie, iż większość Austriaków posługuje się na co dzień dialektem (49\%) lub językiem potocznym (49\%), natomiast zaledwie 2\% używa języka standardowego, tzw. „Hochdeutsch”. Aleksander Szulc (1999, 166) twierdzi, iż Austriacy rozumieją konieczność opanowania języka standardowego wolnego od regionalizmów, a nawet podaje, którzy z nich i w jakich sytuacjach go używają:

Tą odmianą języka posługują się w Austrii nauczyciele i uczniowie podczas nauki szkolnej, profesorowie wyższych uczelni w czasie wykładów, a także politycy i wszelkie osoby urzędowe w oficjalnych przemówieniach. Języka standardowego używa również Austriak w rozmowie z użytkownikami innych odmian języka standardowego lub z mówiącymi po niemiecku cudzoziemcami. Austriacka odmiana języka standardowego obowiązuje również spikerów radiowych i prezenterów TV. Jednak wymowa standardowa Austriaków zachowuje, z nielicznymi tylko wyjątkami, wyraźne zabarwienie regionalne zarówno w realizacji alofonicznej fonemów języka literackiego, jak i w ogólnym przebiegu intonacyjnym. Skodyfikowaną wymowę sceniczną usłyszeć można jedynie u nielicznych specjalnie szkolonych w sztuce żywego słowa aktorów.

$\mathrm{Z}$ reguły wiedza polskich germanistów o austriackiej odmianie języka niemieckiego ogranicza się do poznania zaledwie kilku austriacyzmów z zakresu języka standardowego, np. ${ }^{7}$ styczeń: Jänner (AT) - Januar (DE), luty: Febrer (AT) - Februar $(D E)$, w tym roku: heuer $(A T)$ - dieses $J a h r(D E)$, lub z zakresu języka specjalistycznego, a zwłaszcza słownictwa gastronomiczno-kuchennego, np. pomidory: Paradeiser $(A T)-$ Tomaten (DE), ziemniaki: Erdäpfel (AT) - Kartoffeln (DE), chrzan: Kren (AT) Meerrettich $(D E)^{8}$.

Niemczyzna austriacka jest nasycona dużą ilością italianizmów i latynizmów, podczas gdy niemczyzna w RFN preferuje raczej galicyzmy. Wyrazy używane przez Austriaków pochodzące z łaciny to np. Matura - egzamin dojrzałości, Evidenz - rejestr, a z języka włoskiego to np. Assekuranz - ubezpieczenie, Polizze - polisa. Nie bez znaczenia są również powiązania historyczne Austriaków z krajami słowiańskimi (zwłaszcza Czechami, Słowakami, a nawet Serbami, Chorwatami czy Polakami), a także narodem węgierskim w ramach prężnie funkcjonującej monarchii habsburskiej. Stąd austriacka odmiana języka niemieckiego zapożyczyła wiele wyrazów z języków tychże krajów, szczególnie w przypadku kulinariów, np. z języka włoskiego: Karfiol - kalafior, Ribisel - porzeczka, z języka czeskiego: Powidl - powidła śliwkowe, Kolatsche - kołacz, z języka węgierskiego: Gulasch - gulasz, Palatschinke - naleśnik z nadzieniem, z języka serbo-chorwackiego: Kukuruz - kukurydza, z języka polskiego: Agrasel - agrest (por. Utri 2012, 414).

Oprócz różnic leksykalnych należy wymienić także zjawiska morfologiczne charakterystyczne dla niemczyzny austriackiej (por. Kubacki 2011a, 213). Do zmian morfologicznych możemy zaliczyć m.in. użycie rodzajnika określonego przed imionami i nazwiskami osób, np. der Hans, der Herr Müller, użycie celownika zamiast dopełniacza po przyimku wegen $-z$ powodu czy zamiłowanie Austriaków do stosowania form zdrobniałych tworzonych przy pomocy sufiksu -l i -erl, np. Hunderl-piesek, Dirndl-

\footnotetext{
${ }^{7}$ Przy przykładach podano skróty nazw krajów niemieckojęzycznych zgodnie ze standardem ISO nr 3166-1, tj. DE - Niemcy, AT - Austria, CH - Szwajcaria.

${ }^{8}$ Więcej przykładów zob. A.D. Kubacki (2011a, 212-213).
} 
Artur Dariusz Kubacki, Policentryzm w niemieckim języku standardowym...

młoda dziewczyna. Ponadto różnice dotyczą także użycia innego rodzaju gramatycznego, np. SMS: das SMS (AT) - die SMS (DE), e-mail: das E-Mail (AT) - die E-Mail (DE), któremu towarzyszy czasami ucięcie podstawy słowotwórczej rzeczownika, np. der Akt $(A T)$ - die Akte $(D E)$. W Austrii częściej tworzy się liczbę mnogą rzeczowników z przegłosem, np. samochody: Wägen (AT) - Wagen (DE), kotnierze: Krägen (AT) Kragen $(D E)$, oraz w inny sposób i częściej łączy się leksemy w złożenia za pomocą interfiksu -(e)s- oddzielającego człon określany od określającego, np. ruch kolejowy: Zugsverkehr (AT) - Zugverkehr (DE), egzamin wstęnny: Aufnahmsprüfung (AT) Aufnahmeprüfung (DE), sąd 2. instancji: Landesgericht (AT) - Landgericht (DE). Aleksander Szulc (1999, 185) podaje, iż interfiks -(e)s- w austriackich złożeniach rzeczownikowych jest bardziej produktywny niż w odmianie wewnątrzniemieckiej.

W odniesieniu do zmian syntaktycznych w austriackiej odmianie języka niemieckiego dominuje zanik czasu przeszłego prostego (Präteritum) w języku mówionym oraz tworzenie czasu przeszłego złożonego (Perfekt) od czasowników oznaczających pozycję bądź ułożenie ciała sitzen - siedzieć, liegen - leżeć, stehen - stać, hocken - kucać, hängen - wisieć z czasownikiem posiłkowym sein a nie haben, jak to jest w standardowej niemczyźnie. Aleksander Szulc (1999, 186-187) oraz Jakob Ebner (2013, 473) wskazują także na nieliczne różnice składniowe uwidaczniające się w odmiennym użyciu przyimków: am zamiast auf dem, np. na wsi: am Land (AT) - auf dem Land (DE), über zamiast auf, np. na wniosek: über Antrag (AT) - auf Antrag (DE), um zamiast für, np. kupić za $5 €$ : um $5 €$ kaufen $(A T)$ - für $5 €$ kaufen (DE), oraz odmiennym szyku wyrazów w niektórych frazach, jak np. w prawie każdym sklepie: in beinahe jedem Geschäft (AT) - beinahe in jedem Geschäft (DE).

Jeśli chodzi o ortografię, to po wielkich reformach ortograficznych z 1996 i 2006 r. przeprowadzonych w krajach niemieckojęzycznych różnice w zapisie wyrazów w Austrii są niewielkie. I tak na przykład dopuszczalny jest zapis oboczny takich wyrazów, jak Tunell (Tunnel), Kücken (Küken), Spass (Spaß).

Warto również wspomnieć o typowych dla Austrii idiomach sytuacyjnych, które - zdaniem Aleksandra Szulca $(1999,160)$ - świadczą o innego typu życiu towarzyskim aniżeli w północnych Niemczech, np. Küß die Hand - całuję raczki, gnädige Frau taskawa pani, Habe die Ehre - mam zaszczyt, Grüß Gott-szczęść Boże.

\section{Specyfika standardu języka niemieckiego w niemieckojęzycznej Szwajcarii}

Przypomnijmy, iż około 73\% mieszkańców siedmiomilionowej Szwajcarii uznaje za swój główny język niemczyznę, $13 \%$ to Szwajcarzy francuskojęzyczni, a około $6,5 \%$ mówi po włosku. Jest też $0,5 \%$ populacji władającej językiem retoromańskim, natomiast pozostałe 7\% używa różnych języków niebędących językami urzędowymi Konfederacji ${ }^{9}$.

Jak podaje Ulrich Ammon (1996, 157), niemczyzna używana w Szwajcarii jest traktowana obecnie jako wariant narodowy (nationale Variätet). Kurt Meyer $(2006,16)$ określa ją szwajcarskim wariantem standardowego języka niemieckiego (schweizerische

${ }^{9}$ Języka retoromańskiego (romansz) używa się w okolicach Sankt Moritz w kantonie Gryzonia (Graubünden). Dane dotyczące liczby osób posługujących się danym językiem ojczystym pochodzą ze spisu powszechnego $\mathrm{z}$ ludności $\mathrm{z} 2000 \mathrm{r}$. podanych $\mathrm{W}$ Wikipedii http://pl.wikipedia.org/wiki/Szwajcaria (3.11.2013 r.).

168 


\section{Comparative Legilinguistics 17/2014}

Standardvariätet des Deutschen). Typowe dla Szwajcarii cechy niemczyzny skodyfikowane w niektórych słownikach języka niemieckiego określa się - jak już podano wcześniej - mianem helwetyzmów. Według Beata Siebenhaara i Alfreda Wylera (1997, 9) w niemieckojęzycznej Szwajcarii mamy do czynienia z dwiema formami języka niemieckiego: ze standardowym językiem niemieckim, określanym jako „Schriftdeutsch” lub „Hochdeutsch” (jest on de facto pierwszym językiem obcym nauczanym w szkole od trzeciej klasy szkoły podstawowej), oraz z językiem bazującym na dialektach alemańskich, tzw. „Schwyzerdütsch“"10, który przybiera postać różnych dialektów regionalnych. Aleksander Szulc $(1999,89)$ nazywa go językiem helwetoniemieckim. Dialekty szwajcarskie tak bardzo różnią się od standardowego języka niemieckiego, iż filmy, w których się nimi mówi, zwykle wyświetla się z napisami w języku literackim (Schriftdeutsch), gdyż nawet dla Niemców czy Austriaków dialekty te są niemal całkowicie niezrozumiałe.

Schwyzerdütsch występuje głównie w języku mówionym, bardzo rzadko pisanym (por. Szulc 1999, 90). Taką sytuację językową w Szwajcarii Beat Siebenhaar i Alfred Wyler (1997, 9-10) określają pojęciem dyglosji (Diglossie), czyli posługiwania się przez społeczność dwoma językami, które cieszą się różnym prestiżem i używane są w różnych sytuacjach i sferach życia w taki sposób, iż kontekst ściśle determinuje, który z języków będzie użyty. Swoją opinię naukowcy (1997, 9-10) sformułowali w następujący sposób:

In einer Sprachgemeinschaft werden zwei Formen der gleichen Sprache verwendet, eine hochsprachliche und eine volkssprachliche, und jede Sprachform hat unterschiedliche Geltungsbereiche. Dabei sind die Sprachformen immer deutlich voneinander unterschieden, Misch- und Übergangsformen gibt es kaum. Deutschschweizern ist immer bewusst, welche Sprachform sie verwenden. Wenn sie in bestimmten Situationen zur Hochsprache wechseln (wechseln müssen), so wird das auch meist thematisiert. Ein allmähliches Hinübergehen vom Dialekt in die Hochsprache gibt es nicht.

W niemieckojęzycznej Szwajcarii nie ma języka potocznego, tak jak to jest w przypadku Austrii czy Niemiec (por. Szulc 1999, 89; Meyer 2006, 19). Niemczyzna używana w Szwajcarii - zdaniem Kurta Meyera (2006, 16-17) - nie jest ani gorszym, ani mniej wartościowym standardem języka niemieckiego, a jej szczególne cechy narodowe i regionalne należy postrzegać jako równouprawnione wersje języka niemieckiego.

Jak zauważa Aleksander Szulc (1999, 152-153), dla Helwetów niemczyzna standardowa wciąż odgrywa znaczącą rolę w życiu, zwłaszcza zawodowym. Jest ona niezastąpionym środkiem komunikacji w kontaktach z mieszkańcami pozostałych krajów niemieckojęzycznych, szczególnie w odniesieniu do komunikacji pisemnej (dokumenty urzędowe, handlowe, listy prywatne). Również teksty naukowe, literatura piękna i poezja tworzone są w niemieckim języku standardowym, choćby - jak argumentuje ten badacz ze względu na ich przynależność do ogólnego dorobku nauki i literatury niemieckojęzycznej.

Podobnie jak w Austrii niemczyzna używana w Szwajcarii różni się od standardowej niemczyzny Niemców. Różnice te dotyczą tych samych płaszczyzn językowych: leksykalnej, morfologicznej, syntaktycznej, a także fonetycznej (por. Ammon 1995, Meyer 2006).

${ }^{10}$ Inne warianty graficzne to Schwyzertütsch lub Schwyzertüütsch. 
Artur Dariusz Kubacki, Policentryzm w niemieckim języku standardowym...

Wymowa i intonacja szwajcarska nie jest w sposób szczególny unormowana, a kształtują ją głównie normy regionalne (miejscowe dialekty). Jest ona twardsza od standardowej niemczyzny, co przejawia się - jak podaje Aleksander Szulc $(1999,152)-$ choćby brakiem redukcji w wygłosie oraz całkowitym brakiem palatalnego spirantu [ç]. Dodatkowo pojawia się w niej wiele wymawianych oryginalnie zapożyczeń z języków romańskich, zwłaszcza francuskiego i włoskiego.

Niemieckojęzyczni Szwajcarzy po warstwie leksykalnej tekstu są w stanie rozpoznać, czy tekst zredagował ich krajan czy też Niemiec. Przytoczmy kilka przykładów z codziennej leksyki używanej przez Helwetów: bilet: Billet $(\mathrm{CH})$ Fahrschein/Fahrkarte (DE), telefon komórkowy: Natel (CH) - Handy (DE), chodnik: Trottoir $(\mathrm{CH})$ - Bürgersteig $(D E)$. Jak widać z podanych przykładów, w szwajcarskim standardzie używa się wielu zapożyczeń z języka francuskiego. Ponadto w codziennym użyciu jest wiele wyrazów obcych z języka włoskiego, jak np. zaliczka: Akonto $(\mathrm{CH})-$ Anzahlung (DE), kontrolować coś urzędowo $i$ odbierać: kollaudieren (CH) kontrollieren (DE), języka angielskiego, np. samochód: Car (CH) - Wagen (DE), suszarka bębnowa: Tumbler (CH) - Wäschetrockner (DE), a zwłaszcza łaciny, np. wsparcie finansowe: Subsidium $(\mathrm{CH})$ - finanzielle Unterstützung (DE), referendum: Referendum $(\mathrm{CH})$ - Volksabstimmung $(\mathrm{DE})$. Ponadto występuje tu także wiele terminów specjalistycznych, które różnią się od tych używanych przez Niemców, np. prawo jazdy: Führerausweis $(\mathrm{CH})$ - Führerschein $(\mathrm{DE})$, prawo zobowiazań: Obligationenrecht $(\mathrm{CH})$ Schuldrecht $(D E)$.

W zakresie morfologii możemy dostrzec różnice m.in.:

(i) $\quad \mathrm{w}$ rodzaju gramatycznym rzeczowników, np. Prozent, Radio, Taxi są w Szwajcarii rodzaju męskiego, a w Niemczech rodzaju nijakiego,

(ii) w odmiennym modelu tworzenia liczby mnogiej, np. der Park: die Pärke (CH) die Parks $(D E)$,

(iii) w odmiennym tworzeniu czasowników na -ieren, np. parkieren $(\mathrm{CH})$ - parken $(D E)$,

(iv) $\mathrm{W}$ odmiennej rekcji przyimków łączących się $\mathrm{w}$ niemczyźnie zwykle z dopełniaczem, a w standardzie szwajcarskim z celownikiem, np. hinsichtlich, zufolge,

(v) w odmiennym tworzeniu form zdrobniałych za pomocą sufiksu -(e)li, - schi, np. Bretzli, Knöpfli, Büebschi, i w częstszym użyciu deminutiwów.

W odniesieniu do składni w niemieckojęzycznej Szwajcarii - podobnie jak w Austrii - dominuje tworzenie czasu przeszłego złożonego Perfekt od czasowników oznaczających pozycję bądź ułożenie ciała sitzen - siedzieć, liegen - leżeć, stehen - stać, hocken - kucać, hängen - wisieć z czasownikiem posiłkowym sein a nie haben.

Ponadto różnice uwidaczniają się także w zapisie wyrazów przez Helwetów, ponieważ zamiast ligatury $\beta$ (tzw. $s$ basowego) używa się podwójnego ss. Na klawiaturach komputerowych znajduje się też wiele liter francuskich ze znakami diakrytycznymi, np. Eiscrème, Entrecôte, Café mélange, gdyż tradycją jest zapisywanie wyrazów w formie oryginalnej. Ponadto niektóre wyrazy Szwajcarzy zapisują inaczej niż Niemcy, np. Müesli (CH) - Müsli (DE), Bretzel (CH) - Brezel (DE), Trassee (CH) Trasse (DE). 


\section{Comparative Legilinguistics 17/2014}

\section{Kodyfikacja austriackiego oraz szwajcarskiego języka prawa ${ }^{11}$}

Zarówno w przypadku standardu austriackiego, jak i szwajcarskiego istnieje kilka opracowań leksykograficznych kodyfikujących język ogólny i specjalistyczny (zob. Kubacki 2011a, 214-215). W odniesieniu do austriackiego języka prawa za najważniejszą ekspertkę w tej dziedzinie uchodzi Heidemarie Markhardt. Jej przygoda $\mathrm{z}$ tą terminologią fachową zaczęła się w 1993r., gdy rozpoczęła praktykę jako tłumacz w służbach translatorskich Komisji Europejskiej. W tym okresie powstał w Brukseli pierwszy niepublikowany glosariusz austriackiego języka prawa i administracji jej autorstwa zawierający około 1200 haseł (Markhardt 2006, 11). W 2006 r. opublikowała ona nakładem wydawnictwa Peter Lang pierwszy słownik poświęcony austriackiej terminologii prawa, ekonomii i administracji pt. Wörterbuch der österreichischen Rechts, Wirtschafts- und Verwaltungsterminologie.

W przypadku języka prawa skodyfikowanego w Szwajcarii na szczególną uwagę zasługuje natomiast słownik opracowany przez Petera Metzgera (2005) pt. Schweizerisches juristisches Wörterbuch, który oprócz definicji pojęć prawnych zawiera przy niektórych hasłach ich synonimy i/lub antonimy. W dwóch jego wydaniach uwzględniono ponad 10.000 haseł $\mathrm{z}$ zakresu prawa publicznego, prywatnego oraz międzynarodowego. Jest on odpowiednikiem znanego niemieckiego słownika prawniczego Creifeldsa Rechtswörterbuch (2011), którego obecne 21. wydanie zawiera ponad 12.000 terminów $\mathrm{z}$ różnych dziedzin prawa, a który zalicza się do kanonu literatury prawników.

Oprócz wspomnianych powyżej słowników kodyfikujących język prawa warto również wymienić tzw. Variantenwörterbuch des Deutschen, opracowany w 2004 r. pod redakcją wielu znakomitych badaczy zjawiska pluricentryzmu w niemczyźnie (m.in. Ulricha Ammona, Hansa Bickela). Słownik ten uwzględnia nie tylko słownictwo ogólne, lecz także prawnicze języka niemieckiego używane w ośrodkach pełnych i półośrodkach językowych.

$\mathrm{Na}$ uwagę zasługują również niektóre opracowania naukowe poświęcone zagadnieniu pluricentryzmu języka niemieckiego, w których zestawiono listy ze słownictwem fachowym. I tak na przykład Ulrich Ammon (1995, 259-277) sporządził listy $\mathrm{z}$ leksemami specjalistycznymi obejmującymi siedem zakresów tematycznych, w tym jedna $\mathrm{z}$ nich dotyczy dziedziny administracji, prawa, zdrowia, edukacji i wojska. Podobne listy ze słownictwem specjalistycznym, w tym także z dziedziny prawa, można znaleźć w opracowaniach leksykograficznych z serii Dudena poświęconych odmianie austriackiej (Ebner 2013, 451-452) i szwajcarskiej (Bickel/Landolt 2012, 83).

Nie bez znaczenia $w$ pracy tłumaczy są również opracowania bilingwalne dotyczące języka fachowego. Za przykład w tym kontekście mogę podać minisłownik opracowany w 1997 r. przez Austriacki Związek Tłumaczy Sądowych (Österreichischer Verband der Gerichtsdolmetscher) pt. Die österreichische Rechtsterminologie. Jest to niemiecko-polska lista słów uporządkowana według 16 gałęzi prawa, w tym prawa cywilnego, karnego i handlowego, zawierająca reprezentatywne terminy $\mathrm{z}$ tych gałęzi prawa.

\footnotetext{
${ }^{11}$ Przez język prawa rozumiem zarówno język prawny, w którym formułowane jest prawo, jak i język prawniczy, którym posługujemy się, mówiąc o prawie (metajęzyk).
} 
Artur Dariusz Kubacki, Policentryzm w niemieckim języku standardowym...

Ponadto ze względu na walory dydaktyczne warto zarekomendować zbiory tekstów paralelnych zawierające reprezentatywne teksty specjalistyczne $\mathrm{z}$ Austrii, Szwajcarii i Niemiec. Stanowią one dla tłumaczy nie tylko źródło autentycznie stosowanej terminologii, ale są także wzorcem sposobu utekstowienia treści w warstwie stylistycznej i składniowej. Są one niezwykle przydatne w ustalaniu ekwiwalencji funkcjonalnej szczególnie podczas przekładu tekstów prawniczych. Do wspomnianych antologii - w przypadku języka niemieckiego - należy m.in. zbiór austriackich dokumentów dla tłumaczy sądowych pod red. Zofii Krzysztoforskiej-Weisswasser (1994) oraz trzy wybory tekstów paralelnych do ćwiczeń translacyjnych pod red. Jana Iluka i Artur D. Kubackiego (2003, 2006) oraz Artura D. Kubackiego (2011).

\section{Pluricentryzm w języku specjalistycznym na przykładzie języka prawa}

Zjawisko pluricentryzmu jest również widoczne w leksyce specjalistycznej występującej w niemieckim języku prawnym i prawniczym Niemiec, Austrii i Szwajcarii. Do wytworzenia różnych terminów prawnych używanych w tych trzech państwach niemieckojęzycznych doprowadziły m.in. różne struktury władzy ustawodawczej i wykonawczej ${ }^{12}$. Jak słusznie zauważają Hans Bickel i Christoph Landolt $(2013,83)$, każde państwo posiada specyficzne instytucje, własne orzecznictwo, a także odrębną tradycję administracyjną. Ponadto - jak wspomniałem już w moich badaniach (2011a, 218) - czasami wymianie ulegają nie tylko pojedyncze terminy, lecz także całe zwroty prawnicze stosowane w obrocie prawnym na terenie Niemiec, Austrii czy Szwajcarii, a zatem mamy do czynienia $\mathrm{z}$ odmienną frazeologią specjalistyczną.

Podejmując rozważania nad językiem prawa z perspektywy pluricentrycznej, chciałbym stanowczo podkreślić, iż ów język specjalistyczny postrzegam przez pryzmat terminologii odnoszącej się do systemu prawa danego kraju niemieckojęzycznego. Dlatego w pełni zgadzam się z tezą Gérarda-René de Groota $(1999,204)$, że w przypadku niemieckiego języka prawa trzeba wyróżnić terminologię austriacko-niemiecką, niemiecko-niemiecką, helweto-niemiecką, liechtensteińsko-niemiecką, belgijskoniemiecką, włosko-niemiecką, a nawet europejsko-niemiecką, gdyż ta ostatnia ma bezpośredni wpływ na kształtowanie systemów prawa narodowego.

$\mathrm{Na}$ przykładzie prawa rodzinnego chciałbym wskazać na teutonizmy, austriacyzmy i helwetyzmy w języku prawnym i prawniczym. Na wstępie należy stwierdzić, iż prawo rodzinne jest uregulowane w różnych aktach prawych, które notabene mają także odmienne motywy nazwotwórcze: $w$ Niemczech jest to Bürgerliches Gesetzbuch (BGB), w Austrii Allgemeines Bürgerliches Gesetzbuch (ABGB), a w Szwajcarii Zivilgesetzbuch $(\mathrm{ZGB})^{13}$.

\footnotetext{
${ }^{12}$ Liczne przykłady dotyczące odmiennych w Austrii i Niemczech nazw administracji publicznej, urzędów państwowych, wymiaru sprawiedliwości, zawodów prawniczych czy też nazw środków zaskarżenia, a nawet osób występujących w różnych rolach na sali sądowej można znaleźć w opracowaniu A.D. Kubackiego (2011a).

${ }^{13}$ Regulacje dotyczące prawa rodzinnego w krajach niemieckojęzycznych znajdują się w Księdze Czwartej niemieckiego Kodeksu cywilnego (§§ 1297 do 1921 BGB), Części Pierwszej austriackiego Powszechnego kodeksu cywilnego ( $§ 44$ do 283 ABGB) oraz Księdze Drugiej szwajcarskiego Kodeksu cywilnego (art. 90 do 456 ZGB). W Polsce tej dziedzinie prawa poświęcono odrębny akt prawny: Kodeks rodzinny i opiekuńczy.
}

172 


\section{Comparative Legilinguistics 17/2014}

Wiele instytucji prawnych z zakresu prawa rodzinnego określanych jest w tych trzech krajach niemieckojęzycznych w ten sam sposób, np. rozwód-Scheidung, wspólne pożycie - Lebensgemeinschaft, uznanie ojcostwa - Anerkennung der Vaterschaft. Jednak wiele terminów i instytucji prawnych różni się od siebie ze względu na różne porządki prawne, mimo iż oparte są one na prawie rzymskim. Ponadto różnice leksykalne dotyczą także nazewnictwa kwestii proceduralnych widocznego w pismach wydawanych przez sądy (język prawniczy) krajów niemieckojęzycznych. Należy do nich m.in.:

(i) nazewnictwo orzeczenia sądowego uwarunkowane zastosowaniem odpowiedniej procedury prawnej (procesowej lub nieprocesowej), np. wyrok: Urteil (DE, AT, $C H)$, postanowienie: Beschluss $(D E, A T)$, Entscheid $(C H)$, przy czym procedura nieprocesowa także określana jest inaczej w różnych krajach niemieckojęzycznych: postępowanie nieprocesowe - Außerstreitverfahren (AT), Angelegenheiten der freiwilligen Gerichtsbarkeit (DE), Angelegenheiten der nicht streitigen Gerichtsbarkeit lub Verfahren auf einseitiges Vorbringen $(\mathrm{CH})$.

(ii) określanie nazw stron biorących udział w rozwodzie, np. powód/pozwany Kläger/Beklagter (CH), Antragsteller/Antragsgegner - wnioskodawca/uczestnik postepowania (DE), pierwszy/drugi wnioskodawca Erstantragsteller/Zweitantragsteller (AT) przy rozwodzie za porozumieniem stron lub strona pozywajaca/strona pozwana - klagende Partei/beklagte Partei $(A T)$ przy rozwodzie spornym,

(iii) nazewnictwo organów wymiaru sprawiedliwości właściwych do rozwiązywania małżeństwa przez rozwód ${ }^{14}$, tj. sądów cywilnych pierwszej instancji: Bezirksgericht $(A T)$, Amtsgericht $(D E)$, natomiast w Szwajcarii określane są odmiennie w zależności od danego kantonu - Bezirksgericht, Amtsgericht, Kreisgericht, Regionalgericht, Kantonalgericht $(\mathrm{CH})$,

(iv) nazewnictwo sekretarzy sądowych sporządzających wyroki lub postanowienia w sprawie rozwodowej, np. sekretarz sadu/kierownik sekretariatu sadu: Gerichtsschreiber (CH), Leiter der Geschäftsabteilung (AT), Justizangestellter als Urkundsbeamter der Geschäftsstelle (DE),

(v) użycie odmiennych zwrotów w rubrum orzeczenia sądowego w sprawie rozwodowej, np. sygnatura akt: GZ - Geschäftszahl (AT), AZ - Aktenzeichen $(D E)$, natomiast w Szwajcarii nie używa się określenia ,sygn. akt”, tylko od razu podaje się numer sprawy; sformułowanie ,sprawa o rozwód”: Sache wegen Ehescheidung/Ehescheidungssache (AT), Sache betreffend Ehescheidung ( $\mathrm{CH})$, Familiensache/Ehsesache (DE),

(vi) nazewnictwo poszczególnych elementów orzeczenia sądowego, np. stan faktyczny: Tatbestand (DE), Erwägungen (CH), uzasadnienie: Entscheidungsgründe/Gründe (DE), Begründung (AT).

$\mathrm{Z}$ powyższych przykładów wynika, iż niezwykle ważne jest, aby studenci translatoryki, czyli de facto przyszli tłumacze, byli uwrażliwiani na porównywanie terminów prawnych i badanie ich zakresu semantycznego. Rola tłumacza specjalistycznego polega także na zestawianiu różnych systemów i terminów prawnych w celu wyszukania podobieństw i różnic. Zadanie to obejmuje nie tylko porównywanie

\footnotetext{
${ }^{14} \mathrm{~W}$ Polsce sądem właściwym do rozwiązywania małżeństwa przez rozwód jest sąd okręgowy, który w innych sprawach jest sądem 2 . instancji.
} 
Artur Dariusz Kubacki, Policentryzm w niemieckim języku standardowym ...

terminów prawa polskiego z terminami prawa niemieckiego, ale także porównywanie systemów prawnych krajów niemieckojęzycznych. Jak słusznie twierdzi Peter Sandrini (1996, 145 i n.), pojęcia prawne różnych systemów prawnych mogą być ekwiwalentne jedynie częściowo lub aproksymatywnie. Potwierdzeniem tej tezy jest choćby jedna $\mathrm{z}$ instytucji systemu małżeńskiego prawa majątkowego w prawie rodzinnym Polski i krajów niemieckojęzycznych, która - jak wykazał Piotr Kuna (2010, 90) - nie jest kompatybilna. Z jego analizy wynika, iż elementem niekompatybilnym jest instytucja Güterstand der Zugewinngemeinschaft, której w polskim systemie prawnym nie ma, a która obejmuje zarówno Gütertrennung - rozdzielność majatkowa, jak i Zugewinn przyrost wartości majątku. Piotr Kuna $(2010,91)$ proponuje dla brakującej instytucji prawa rodzinnego następujący ekwiwalent: rozdzielność majątkowa z późniejszym wyrównaniem przyrostu wartości majątków. Instytucja ustawowego małżeńskiego ustroju majątkowego w innych krajach niemieckojęzycznych występuje pod takimi nazwami, jak ordentlicher Güterstand $(\mathrm{CH})$, gesetzlicher ehelicher Güterstand (AT). Bez analizy systemu prawnego kraju niemieckojęzycznego, z którego pochodzi dany dokument, tłumacz nie będzie w stanie dokonać poprawnego przekładu danej instytucji prawnej na język polski.

Oto kilka przykładów różnic leksykalnych pomiędzy narodowymi odmianami języka niemieckiego udokumentowanych w aktach normatywnych (Tab. 1) oraz w pismach sądowych ${ }^{15}$ (Tab. 2) związanych z prawem rodzinnym.

Tab. 1. Różnice leksykalne udokumentowane w aktach normatywnych

\begin{tabular}{|c|c|c|c|c|}
\hline Poz. & Polska & Szwajcaria & Austria & Niemcy \\
\hline 1. & Pozew o rozwód & Scheidungsbegehren & $\begin{array}{l}\text { 1. Ehescheidungsklage } \\
\text { 2. Antrag auf } \\
\text { einvernehmliche } \\
\text { Ehescheidung }\end{array}$ & Scheidungsantrag \\
\hline 2. & $\begin{array}{l}\text { rozwód za poro- } \\
\text { zumieniem stron }\end{array}$ & $\begin{array}{l}\text { Scheidung auf ge- } \\
\text { meinsames Begehren }\end{array}$ & $\begin{array}{l}\text { einvernehmliche } \\
\text { Scheidung }\end{array}$ & $\begin{array}{l}\text { einverständliche } \\
\text { Scheidung }\end{array}$ \\
\hline 3. & $\begin{array}{l}\text { władza } \\
\text { rodzicielska }\end{array}$ & elterliche Sorge & Obsorge & (elterliche) Sorge \\
\hline 4. & $\begin{array}{l}\text { zupełny i trwały } \\
\text { rozkład pożycia }\end{array}$ & $\begin{array}{l}\text { tiefe und unheilbare } \\
\text { Zerrüttung der Ehe }\end{array}$ & $\begin{array}{l}\text { tiefgreifende und un- } \\
\text { heilbare Zerrüttung der } \\
\text { Ehe }\end{array}$ & Scheitern der Ehe \\
\hline 5. & $\begin{array}{l}\text { przedmioty } \\
\text { zwykłego } \\
\text { urządzenia } \\
\text { domowego }\end{array}$ & Hausrat & $\begin{array}{l}\text { eheliches Gebrauchs- } \\
\text { vermögen }\end{array}$ & $\begin{array}{l}\text { Gegenstände des } \\
\text { ehelichen } \\
\text { Haushalts }\end{array}$ \\
\hline 6. & sąd opiekuńczy & $\begin{array}{l}\text { Vormundschafts- } \\
\text { behörde }\end{array}$ & Pflegschaftsgericht & $\begin{array}{l}\text { Familiengericht, } \\
\text { früher: } \\
\text { Vormundschaftsger } \\
\text { icht }\end{array}$ \\
\hline 7. & opiekun & Vormund & Kurator & Vormund \\
\hline
\end{tabular}

${ }^{15} \mathrm{~W}$ skład analizowanych przeze mnie pism sądowych wchodzą jedynie orzeczenia sądowe (wyroki i postanowienia sądowe) z Niemiec, Austrii i Szwajcarii, które zostały opublikowane w antologiach tekstów specjalistycznych (zob. Kubacki, 2006, 2011) jako materiał dydaktyczny do nauczania thumaczenia specjalistycznego. 
Comparative Legilinguistics 17/2014

\begin{tabular}{|c|l|l|l|l|}
\hline 8. & $\begin{array}{l}\text { majątkowa } \\
\text { umowa } \\
\text { małżeńska }\end{array}$ & Ehevertrag & Ehepakt & Ehevertrag \\
\hline 9. & $\begin{array}{l}\text { dziecko } \\
\text { przysposobione }\end{array}$ & Kind & Wahlkind & (Adoptiv)kind \\
\hline 10. & adopcja & Adoption & Annahme an Kindestatt & Annahme als Kind \\
\hline
\end{tabular}

Tab. 2. Różnice leksykalne udokumentowane w pismach sądowych

\begin{tabular}{|c|c|c|c|c|}
\hline Poz. & Polska & Szwajcaria & Austria & Niemcy \\
\hline 1. & $\begin{array}{l}\text { zasiłek } \\
\text { alimentacyjny, } \\
\text { alimenty }\end{array}$ & $\begin{array}{l}\text { Alimente; } \\
\text { Unterhaltsbeitrag }\end{array}$ & $\begin{array}{l}\text { Unterhalt; } \\
\text { Unterhaltsleitung }\end{array}$ & $\begin{array}{l}\text { Unterhalt } \\
\text { Unterhaltszahlung }\end{array}$ \\
\hline 2. & protokolant sądowy & Gerichtsschreiber & Protokollführer & Protokollführer \\
\hline 3. & wpis tymczasowy & Einschreibegebühr & Pauschalgebühr & $\begin{array}{l}\text { Gerichtskostenvorsch } \\
\text { uss }\end{array}$ \\
\hline 4. & $\begin{array}{l}\text { klauzula } \\
\text { prawomocności }\end{array}$ & $\begin{array}{l}\text { Rechtskraft- } \\
\text { bescheinigung }\end{array}$ & $\begin{array}{l}\text { Rechtskraftklausel } \\
\text { Rechtskraftbestätigung }\end{array}$ & Rechtskraftzeugnis \\
\hline 5. & rzeczy osobiste & $\begin{array}{l}\text { persönliche } \\
\text { Effekten }\end{array}$ & persönliche Effekten & $\begin{array}{l}\text { Private } \\
\text { Habseligkeiten, } \\
\text { private bewegliche } \\
\text { Habe }\end{array}$ \\
\hline 6. & księga małżeństw & Eheregister & Ehebuch & $\begin{array}{l}\text { Familienbuch ab } \\
\text { 1.01.2009: Ehebuch }\end{array}$ \\
\hline 7 & umowa rozwodowa & $\begin{array}{l}\text { Scheidungs- } \\
\text { konvention }\end{array}$ & Scheidungs-vereinbarung & $\begin{array}{l}\text { Scheidungs- } \\
\text { vereinbarung }\end{array}$ \\
\hline 8. & małżeństwo pozorne & Scheinehe & $\begin{array}{l}\text { Namensehe } \\
\text { Staatsbürgerschaftsehe }\end{array}$ & Scheinehe, Zweckehe \\
\hline 9. & USC & Zivilstandsamt & Standesamt & Standesamt \\
\hline 10. & $\begin{array}{l}\text { kancelaria } \\
\text { adwokacka }\end{array}$ & Advokaturbüro & Rechtsanwaltskanzlei & Rechtsanwaltskanzlei \\
\hline
\end{tabular}

Z badań frekwencji użycia terminów prawnych Michaela Kucharskiego (2009, 217) w prawie spadkowym i rodzinnym wynika, iż jedynie niektóre terminy można w sposób jednoznaczny przyporządkować do terminologii prawnej danego kraju niemieckojęzycznego, tj. Niemiec, Austrii czy Szwajcarii. Stąd trudno jest w jego opinii jednoznacznie mówić o „czystych” austriacyzmach w przebadanych przez niego gałęziach prawa, skoro wiele terminów używanych obecnie w Austrii było używane 
Artur Dariusz Kubacki, Policentryzm w niemieckim języku standardowym...

kiedyś w Niemczech. O zakwalifikowaniu danego terminu do leksyki fachowej charakterystycznej dla danego kraju niemieckojęzycznego świadczy raczej - zdaniem Michaela Kucharskiego - frekwencja jego użycia w języku prawniczym, a więc na przykład w wydawanych orzeczeniach sądowych. Ponadto badacz ten $(2009,166)$ zwraca uwagę na różny zakres semantyczny niektórych podobnych do siebie terminów prawnych, gdyż nie pokrywa się on w pełni z zakresem semantycznym tych terminów we wszystkich krajach niemieckojęzycznych, mimo iż mamy do czynienia z podobnie zbudowanymi porządkami prawnymi, np. władza rodzicielska: Obsorge w Austrii, elterliche Sorge w Niemczech i Szwajcarii. W Austrii termin ten uwzględnia zarówno obowiązek opieki nad małoletnim dzieckiem, obowiązek jego wychowywania, zarządzania jego majątkiem i ustawowego reprezentowania, a także prawo do wymienionych czynności (por. art. 144 ABGB). W Niemczech ustawa nie wspomina o wychowywaniu małoletniego dziecka (por. § 1626 i n. BGB), natomiast w Szwajcarii ustawodawca wspomina zaledwie o takiej instytucji prawnej, nie definiując bliżej, co do jej zakresu należy (por. art. 296 i n. ZGB).

Język prawa charakteryzuje się wysokim stopniem sformalizowania. W dokumentach sądowych można znaleźć standardowe zwroty i wyrażenia prawnicze, dzięki którym zachowana zostaje jednolitość komunikacji prawniczej, wysoki stopień abstrakcyjności, a także racjonalność i bezemocjonalność orzeczenia sądowego. Oto dwa przykłady zwrotów skonwecjonalizowanych (sformalizowanych) używanych w orzeczeniach sądowych, pierwszy dotyczy kosztów sądowych, drugi odnosi się do klauzuli prawomocności wyroku:

(i) PL: Koszty postępowania stron znosza się wzajemnie ${ }^{16}$.

DE: Die Kosten des Verfahrens werden gegeneinander aufgehoben.

A: Die Kosten des Verfahrens werden gegeneinander aufgehoben.

$\mathrm{CH}$ : Allfällige Parteikosten werden wettgeschlagen.

(ii)

PL: Powyższy wyrok (odpis) jest prawomocny z dniem ...

DE: Vorstehendes Urteil ist rechtskräftig seit dem ...

A: Die Ausfertigung ist materiell rechtskräftig und vollstreckbar seit ...

$\mathrm{CH}$ : Vorstehendes Urteil ist am ... in Rechtskraft erwachsen.

Sieglinde Pommer $(2006,26)$ podkreśla, że w procesie translacyjnym tego typu zwrotów sformalizowanych thumacz nie ma swobody w zakresie ich dowolnego formułowania, lecz powinien oddać je w translacie za pomocą podobnych używanych w języku docelowym zwrotów skonwencjonalizowanych, o ile takie w nim funkcjonują.

$\mathrm{Na}$ koniec chciałbym jeszcze raz powrócić do przeprowadzania komparatystyki prawnej przez tłumacza i podkreślić jej relewantność w aspekcie translatorycznym. Według Petera Sandriniego (1999, 36-37) tłumacz powinien skupić się przede wszystkim na tzw. mikrokomparatystyce (Mikrovergleichung), która zajmuje się porównywaniem gatunków tekstowych i ich specyficznej funkcji w obrębie poszczególnych porządków prawnych. To właśnie dzięki niej tłumacz może rozpoznać różnice także na płaszczyźnie struktury tekstu oraz różnice pragmatyczne.

Analizując teksty orzeczeń w sprawach rozwodowych, wspomnieć należy o różnicy dotyczącej struktury wyroku. W Niemczech wyrok wydaje się $w$ imieniu narodu - im Namen des Volkes, zaś w Austrii w imieniu Republiki - im Namen der

\footnotetext{
${ }^{16}$ Tzn. każda ze stron ponosi koszty za siebie.
} 


\section{Comparative Legilinguistics 17/2014}

Republik $^{17}$. W Szwajcarii natomiast nie stosuje się tego typu sformułowania. Jedynie szwajcarski Sąd Najwyższy wydaje wyroki w imieniu wydziału, w którym go sporządzono. Ponadto różnice formalne widoczne są w samej kompozycji orzeczenia sądowego, a więc przykładowo w odmiennym graficznym rozmieszczeniu różnych jego elementów takich, jak: strony postępowania, ich ustawowi przedstawiciele lub pełnomocnicy procesowi, data i miejsce wydania wyroku oraz tekst tenoru czy klauzula prawomocności. Co więcej, niemieckie i szwajcarskie orzeczenia mają zazwyczaj śródtytuły, austriackie są sporządzane w układzie ciągłym, a polskie wyroki mają wyliczenia wypunktowane. Poza tym w orzeczeniach szwajcarskich i polskich nie stanowi obligatoryjnej części uzasadnienie wyroku lub postanowienia, które sporządzane jest dopiero na wniosek strony.

Różnice pragmatyczne wyrażają się natomiast w podawaniu tytułów akademickich w austriackich dokumentach sądowych zarówno w przypadku wymienianych w nich prawników (skład orzekający, osoby sporządzające orzeczenia sądowe), jak i osób będących stronami postępowania lub ich pełnomocników (por. Kubacki 2011a, 220-221). Ponadto uzusem jest tu także obligatoryjne podawanie w rubrum wyroku zawodów stron biorących udział w rozwodzie. W niemieckich wyrokach rozwodowych można jedynie spotkać stopnie naukowe doktora podawane przy nazwiskach sędziów lub adwokatów, zaś w ich polskich odpowiednikach tytuły zawodowe podawane są czasami przy nazwiskach urzędników sekretariatu sądu właściwych do poświadczania odpisu orzeczenia sądowego z oryginałem.

\section{Wnioski}

Dopiero od dwudziestu lat mówi się o języku niemieckim jako o języku pluricentrycznym w przeciwieństwie do języka francuskiego czy angielskiego, które już od dawna posiadają taki status. Chociaż zjawisko to jest dostrzegane przez lingwistów, jednak nadal nie ma ono wystraczającego odzwierciedlenia w działaniach praktycznych. Dlatego też niezwykle cenne są takie inicjatywy, jak choćby nauczanie języka niemieckiego według koncepcji DACHL ${ }^{18}$ propagowane przez Międzynarodowe Stowarzyszenie Nauczycieli Języka Niemieckiego, które zakłada globalne spojrzenie na język niemiecki, a nie jedynie z perspektywy Republiki Federalnej Niemiec. W aspekcie glottodydaktycznym można dostrzec pierwsze działania nauczycieli mające na celu propagowanie kultury i literatury niemieckojęzycznej, a co za tym idzie zapoznawanie się z różnymi odmianami języka niemieckiego. Trzeba pamiętać, iż język ten jest drugim najpowszechniej znanym językiem obcym w Europie, a w Polsce drugim językiem wybieranym na maturze przez uczniów szkół średnich ${ }^{19}$. W związku z tym niezwykle ważne jest uwrażliwianie zarówno przyszłych nauczycieli, jak i tłumaczy języka niemieckiego na obecność zjawiska pluricentryzmu. Niestety, zarówno w kształceniu uniwersyteckim, jak i pozauniwersyteckim tłumaczy w Polsce nadal brakuje inicjatyw

${ }^{17}$ Podobnie w Polsce wyroki wydaje się w imieniu Rzeczypospolitej Polskiej.

${ }^{18}$ DACHL to skrótowiec dla czterech państw niemieckojęzycznych: Deutschland (D), Österreich (A), Schweiz $(\mathrm{CH})$ i Liechtenstein $(\mathrm{L})$.

19 Dane Centralnej Komisji Egzaminacyjnej dotyczące matury w 2012 r. - www.cke.edu.pl (3.11.2013 r.). 
Artur Dariusz Kubacki, Policentryzm w niemieckim języku standardowym...

w odniesieniu do nauczania przekładu specjalistycznego $\mathrm{z}$ perspektywy pluricentrycznej $^{20}$.

\section{Bibliografia}

Ammon, Ulrich, 1995, Die deutsche Sprache in Deutschland, Österreich und der Schweiz. Das Problem der nationalen Varietäten, Berlin/New York: Walter de Gruyter.

Ammon Ulrich, 1996, Typologie der nationalen Varianten des Deutschen zum Zweck systematischer und erklärungsbezogener Beschreibung nationaler Varietäten, W: Zeitschrift für Dialektologie und Linguistik, Heft 63.2, 157-175.

Ammon, Ulrich, 1998, Plurinationalität oder Pluriarealität? Begriffliche und terminologische Präzisierungsvorschläge zur Plurizentrizität des Deutschen mit einem Ausblick auf ein Wörterbuchprojekt, W: Deutsche Sprache in Raum und Zeit, FS zum 60. Geburtstag von Peter Wiesinger, red. Ernst Patocka, Deutsche Sprache in Raum und Zeit, Wien, 313-322.

Ammon, Ulrich et al. (red.), 2004, Variantenwörterbuch des Deutschen. Die Standardsprache in Österreich, der Schweiz und Deutschland sowie in Liechtenstein, Luxemburg, Ostbelgien und Südtirol, Berlin/New York: Walter de Gruyter.

Bęza, Stanisław, 2004, Eine kleine Landeskunde der deutschsprachigen Länder, Warszawa: PWN.

Bickel, Hans, 2000, Deutsch in der Schweiz als nationale Varietät des Deutschen, W: Sprachreport nr 4, 21-27.

Bickel, Hans, 2001, Schweizerdeutsch; kein minderwertiges Hochdeutsch! Das Deutsche als plurizentrische Sprache aus Schweizer Sicht, W: Babylonia nr 2/01, 19-22.

Bickel, Hans, Landolt, Christoph, 2012, Schweizerhochdeutsch, Wörterbuch der Standardsprache in der deutschen Schweiz, Berlin/Mannheim/Zürich: Dudenverlag.

Bigler, Ingrid, 1987, Unser Wortschatz, Schweizer Wörterbuch der deutschen Sprache. Mit einem umfassenden Textteil zu Wortgebrauch und Grammatik, Zürich: Sabe.

Clyne, Michael George, 1995, The German Language in a Changing Europe, Cambridge: CUP.

Clyne, Michael George, 2005, Plurizentrische Sprachen, W: Soziolinguistik. Ein internationales Handbuch zur Wissenschaft von Sprache und Gesellschaft. 2. vollständig neu bearbeitet und erweiterte Auflage, red. Ammon Ulrich et al. 1. Teilband, 296-300.

Creifelds, Rechtswörterbuch, 2011, 20, neu bearbeitete Auflage, München: C.H. Beck. Dargiewicz, Anna, 2004, DACH-Länder und eine deutsche Sprache? Die sprachliche und kulturelle Besonderheit des Österreichischen, W: Wschód-Zachód. Dialog

20 Warto w tym miejscu wspomnieć o projekcie naukowym ośrodka w Zurychu pt. Standardsprachliche Varianten in Wörterbüchern. Überlegungen zur diatopischen Variation in der deutschsprachigen Lexikographie realizowanym przez Patrizię Sutter, który poświęcony jest uwzględnieniu koncepcji pluricentryzmu języka niemieckiego we współczesnej leksykografii. Dziękuję w tym miejscu recenzentce mojego artykułu za wskazanie na powyższy projekt.

178 
języków i kultur w kontekście globalizacji, red. Zoi Nowożenowa, Grażyna Lisowska, Słupsk: Pomorska Akademia Pedagogiczna w Słupsku, 20-29.

de Cillia, Rudolf, 2006, Varietätenreiches Deutsch. Deutsch als plurizentrische Sprache und DaF-Unterricht, W: Begegnungssprache Deutsch - Motivation, Herausforderung, Perspektiven, red. Hans-Jürgen Krumm/Paul PortmannTselikas, 51-65. Innsbruck et al.: Studien Verlag.

de Groot, Gérard-René, 1999, Zweisprachige juristische Wörterbücher, W: Übersetzen von Rechtstexten - Fachkommunikation im Spannungsfeld zwischen Rechtsordnung und Sprache, red. Peter Sandrini, 203-227. Tübingen: Gunter Narr.

Die österreichische Terminologie. Verzeichnis wichtiger Rechtsbegriffe geordnet nach Rechtsgebieten Deutsch-Polnisch, 1997, Österreichischer Verband der Gerichtsdolmetscher Wien.

Duden, Deutsches Universalwörterbuch, 2011, 7. Auflage, Berlin/Mannheim/Zürich: Dudenverlag.

Dürscheid, Christa et al., red., 2006, Schweizer Standarddeutsch. Beiträge zur Varietätenlinguistik, Tübingen: Gunter Narr.

Ebner, Jakob, 2013, Wie sagt man in Österreich? Wörterbuch des österreichischen Deutsch, 4. völlig überarbeitete Auflage, Berlin/Mannheim/Zürich: Dudenverlag.

Firyn, Sylwia, 2010, Österreichische Standardlexik im ,Duden. Universalwörterbuch“, ,Handwörterbuch der deutschen Gegenwartssprache‘, ,Langenscheidts Großwörterbuch Deutsch als Fremdsprache' sowie in der älteren und neueren Ausgabe des ,Handwörterbuchs Deutsch-Polnisch“ von Jan Chodera, Stefan Kubica und Andrzej Bzdęga, W: Deutsche und polnische Lexikographie nach 1945 im Spannungsfeld der Kulturgeschichte, red. Lech Zieliński et al., 51-64. Frankfurt am Main et al.: Peter Lang.

Firyn, Sylwia, 2012, Regionalizmy w przekładzie na podstawie tłumaczeń niemieckopolskich, W: Rocznik Przekładoznawczy, nr 7, 51-64.

Iluk, Jan, Kubacki, Artur Dariusz, 2003, Wzory polskich i niemieckich dokumentów do ćwiczeń translacyjnych, Katowice: Gnome.

Iluk, Jan, Kubacki, Artur Dariusz, 2006, Wybór polskich i niemieckich dokumentów do ćwiczeń translacyjnych, Warszawa: Promocja XXI.

Krzysztoforska-Weisswasser, Zofia, 1994, Mustersammlung österreichischer Dokumente und Schriftstücke für Gerichtsdolmetscher, Warszawa: TEPIS.

Kubacki, Artur Dariusz, 2011a, Austriacki język prawa - z doświadczeń tłumacza, W: Komunikacja specjalistyczna t. 4, 212-224.

Kubacki, Artur Dariusz, 2011b, Neue Auswahl deutschsprachiger Dokumente, Warszawa: Translegis.

Kubacki, Artur Dariusz, 2012, Ttumaczenie poświadczone. Status, kształcenie, warsztat i odpowiedzialność tlumacza przysięglego, Warszawa: Wolters Kluwer Polska.

Kucharski, Michael, 2009, Austriazismen im Erb- und Familienrecht, unveröffentlichte Diplomarbeit, Wien.

Kuna, Piotr, 2010, Tłumaczenie nacechowanych kulturowo terminów specjalistycznych w niemieckim prawie majątkowym małżonków - ustrój majątkowy 
Artur Dariusz Kubacki, Policentryzm w niemieckim języku standardowym...

Zugewinngemeinschaft, W: Tłumacz wobec problemów kulturowych, Język a komunikacja 26, red. Maria Piotrowska, Kraków: Tertium.

Lang, Elisabeth, 2010, Plurizentrik als Übersetzungsproblem, W: Germanistische Linguistik extra muros - Aufforderungen. Linguistische Treffen in Wrockaw, vol. 5, red. Iwona Bartoszewicz et al., 197-203, Wrocław-Dresden: Oficyna Wydawnicza ATUT-Neisse Verlag.

Markhardt, Heidemarie, 2006, Wörterbuch der österreichischen Rechts-, Wirtschafts- und Verwaltungsterminologie, Frankfurt am Main et al.: Peter Lang.

Metzger, Peter, 2005, Schweizerisches juristisches Wörterbuch einschliesslich Versicherungsrecht mit Synonymen und Antonymen, Basel et al.: Helbing \& Lichtenhahn.

Meyer, Kurt, 2006, Schweizer Wörterbuch. So sagen wir in der Schweiz. Mit einem Beitrag von Hans Bickel, Frauenfeld et al.: Verlag Huber.

Muhr, Rudolf, 1997, Zur Terminologie und Methode der Beschreibung plurizentrischer Sprachen und deren Varietät am Beispiel des Deutschen, W: Österreichisches Deutsch und andere nationale Varietäten plurizentrischer Sprachen in Europa. Empirische Analysen, red. Rudolf Muhr, Richard Schrodt, 40-67, Wien: Verlag öbv \& hpt.

Muhr, Rudolf, red., 2012, Non-Dominant Varieties of Pluricentric Languages. Getting the Picture, Frankfurt am Main et al.: Peter Lang.

Österreichisches Wörterbuch, 2006, 40. neu bearbeitete Auflage, herausgegeben im Auftrags des Bundesministeriums für Bildung, Wissenschaft und Kultur, Wien: Verlag öbv \& hpt.

Paluszek, Karolina. 2014 [w druku]. Die Besonderheiten der österreichischen Rechtssprache. Comparative Legilinguistics [Legilingwistyka Porównawcza] tom $18 / 2014$.

Pollak, Wolfgang, 1994, Österreich und Europa: sprachkulturelle und nationale Identität, Wien.

Pommer, Sieglinde, 2006, Rechtsübersetzung und Rechtsvergleichung. Translatologische Fragen zur Interdisziplinarität, Frankfurt am Main et al.: Peter Lang.

Sandrini, Peter, 1996, Terminologiearbeit im Recht. Deskriptiver begriffsorientierter Ansatz vom Standpunkt des Übersetzers, Wien: TermNet.

Sandrini, Peter, 1999, Translation zwischen Kultur und Kommunikation. Der Sonderfall Recht, W: Übersetzen von Rechtstexten - Fachkommunikation im Spannungsfeld zwischen Rechtsordnung und Sprache, red. Peter Sandrini, 9-43. Tübingen: Gunter Narr.

Siebenhaar, Beat, Wyler, Alfred, 1997, Dialekt und Hochsprache in der deutschsprachigen Schweiz, Zürich: Edition „Pro Helvetia“.

Szulc, Aleksander, 1999, Odmiany narodowe języka niemieckiego. Geneza - rozwójperspektywy, Kraków: Polska Akademia Umiejętności.

Szulc, Aleksander, 2005, Niemiecki język standardowy - od pozornej jedności do realnego pluricentryzmu, W: Przegląd Uniwersytecki nr 3, 25-27.

Utri, Reinhold, 2010, Gibt es dialektale Fachsprachen? Erörterungen am Beispiel des Donauschwäbischen, W: „Komunikacja specjalistyczna“, t. 2, 156-165.

Utri, Reinhold, 2012, Die regionale Vielfalt des Deutschen als Kulturrealität am Beispiel des Österreichischen Deutsch, W: Mensch - Sprachen - Kulturen. Beiträge und 


\section{Comparative Legilinguistics 17/2014}

Materialien der internationalen wissenschaftlichen Jahrestagung des Verbandes Polnischer Germanisten, 25.-27. Mai 2012 Warszawa, red. Grzegorz Pawłowski et al., Warszawa: Euro-Edukacja, 409-422.

Utri, Reinhold, 2013a, Austrian languages for special purposes, W: Lingwistyka Stosowana, t. 7, 165-177.

Utri, Reinhold, 2013b, Die Plurizentrizität der Sprachen - Geschichte, derzeitiger Stand, Ausblicke, W: „Germanica Wratislavienisia“ t. 138, w druku. 
Artur Dariusz Kubacki, Policentryzm w niemieckim języku standardowym... 